\title{
Teaching and Learning English Paradigm and The Implementation of The Policy
}

\author{
Zainal Arifin \\ IAIN Surakarta \\ arizain@gmail.com
}

\begin{abstract}
Theory on Teaching English is currently moving on a paradigm shift. This paradigm occurred because of a review on the basics of linguistic, pedagogic and the review on the impact of sociolinguistics in a globalized setting. This paper aims to show the results of comparative study which is textual on the teaching and learning English paradigm and the policy has been implemented by both universities. The objective of the study is to describe the comparison of the paradigm between English Language Education and academic policy in both universities. Descriptive qualitative in the form of textual analysis is used in this study. Data were taken from the analysis of documents and interviews with academicians in both universities then analyzed using the theory of a paradigm shift in learning English (Kostoulas, 2010) and academic policy (Center for Quality Assurance, UGM, 2012) using an interactive model of Miles and Huberman. The validity of the data used triangulation methods and data sources. The results show that the content of English Language Education taught at the Division of English Language Education (ELE) HKU and at the English Language Education Department (PBI) IAIN Surakarta have the same characteristics but the ways in providing educational materials are relatively different. The paradigm and academic policiy in ELE HKU applied the learning paradigm while at PBI IAIN Surakarta is still applying on teaching paradigm. When the study was conducted by researcher, the ELE Department IAIN Surakarta has been moving towards a paradigm shift in some academic elements as the use of the methods by
\end{abstract}


lecturers called learning paradigm, although the method is not covered by the policy. The difference between Paradigm and policy in both universities is influenced by the context of the political situation, especially the rules of ministry of higher education, cultural context and the orientation on each university.

Keywords: Paradigm Shift, Academic Policy, English Language Education, Intertextual Analysis

\section{Abstrak}

Teori Pengajaran Bahasa Inggris saat ini sedang mengalami pergeseran paradigma. Pergeseran paradigma ini terjadi karena peninjauan kembali dasar-dasar linguistik dan pedagogis serta penilaian ulang dampak sosiolinguistik bahasa Inggris dalam setting yang semakin mengglobal. Artikel ini bertujuan untuk melaporkan hasil penelitian perbandingan tekstual tentang paradigma pengajaran dan pembelajaran bahasa Inggris dan kebijakan yang dimiliki dua jurusan Pendidikan Bahasa Inggris di dua perguruan tinngi yaitu di Hong Kong University (HKU) dan di IAIN Surakarta. Tujuan penelitian tersebut adalah mendeskripsikan perbandingan paradigma pendidikan bahasa Inggris dan kebijakan akademik di kedua perguruan tinggi tersebut. Desain penelitian ini adalah deskriptif kualitatif dalam bentuk analisis intertekstual. Data diambil melalui analisis dokumen dan wawancara dengan sivitas akademika kedua perguruan tinggi dan dianalisis dengan teori pergeseran paradigma pembelajaran bahasa Inggris (Kostoulas, 2010) dan kebijakan akademik (Kantor Jaminan Mutu UGM, 2012) menggunakan interaktif modelnya Miles and Huberman. Keabsahan data menggunakan trianggulasi metode dan sumber data. Hasil penelitian menunjukkan konten pendidikan bahasa Inggris yang diajarkan di Division of English Language Education (ELE) $H K U$ dan di Jurusan Pendidikan Bahasa Inggris (PBI) IAIN Surakarta relatif sama namun cara dan alasan memberikan materi pendidikan bahasa Inggris relatif berbeda. Paradigma dan kebijakan akademik di ELE HKU sudah menganut lerning paradigm sedangkan PBI IAIN Surakarta masih menganut teaching paradigm walaupun saat penelitian ini dilakukan gejala untuk menuju pergeseran paradigma sudah mulai terjadi di beberapa unsur akademik misalnya dalam penggunaan metode bersifat learning paradigm oleh dosen walaupun belum dipayungi oleh kebijakan yang sesuai. Perbedaan paradigma dan kebijakan kedua perguruan tinggi ini dipengaruhi oleh konteks situasi terutama politik pendidikan pemerintah 
yang berkuasa, konteks budaya dan oientasi masing masing perguruan tinngi.

Kata kunci: Pergeseran Paradigma, Kebijakan Akademik, Pendidikan Bahasa Inggris, Analisis Intertekstual

\section{Introduction}

At present, ELT theory appears to be undergoing a paradigm shift which is sustained by a rethinking of its linguistic and pedagogical underpinnings, as well as by a re-appraisal of the sociolinguistic impact of the English language in an increasingly globalized setting (Kostoulas, 2010).

This paradigm shift is also the impact of educational paradigm shift in general that has occurred since the 1950s (Hill, 1999). A paradigm shift is happening slowly but surely. Pergeseran is needed in addition is also desirable (Barr and Tagg, 1995). This fundamental change would have an impact on academic policy changes related to the implementation of teaching and learning in the English Department, especially English as a second or foreign language.

According to the Standards for Foreign Language Learning: Preparing for the 21st Century, language and communication are the heart of the human experience. The quote is a philosophical statement in the foreign language learning in the United States. Regarding with this philosophical statement, there are five simple words that reflect the philosophy of foreign language education adopted to face the 21 st century. Those words are communication, cultures, connections, comparisons, and 
communities. These five words are mutually integrated in the implementation.

Nowadays, ELT is in a transition between two different informing paradigms (Figure 2.1). The dominant paradigm derives its linguistic and pedagogical legitimacy from norms developed in the Anglophone West, and is associated with linguistic hegemony. On the other hand, the emerging paradigm espouses linguistic and pedagogical norms which are bounded by local circumstance, and the position itself critically towards the political implications of ELT. The interaction between these two paradigms seems to generate tension at the points where they interface, namely the questions of which language variety (what) to teach, through which methods (how) and to what end (why) (Kostoulas, 2010)

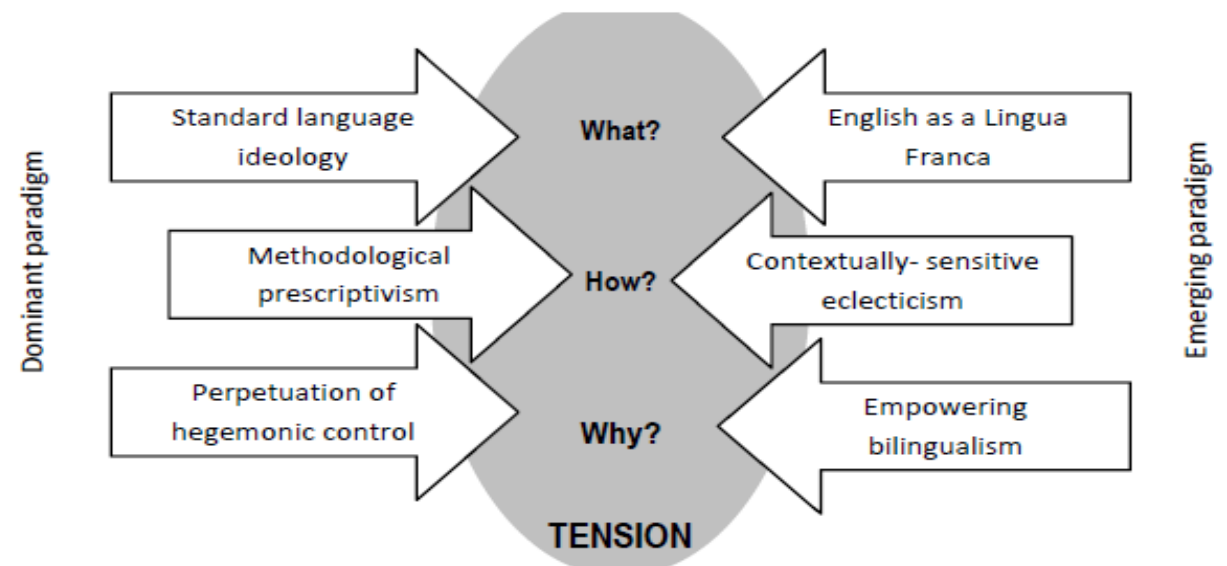

Figure1. Emerging VS Dominant Paradigm Paradigm (Kostoulas 2010) 
In details the differences both paradigam in learning English as a second language can be seen on the table 1 below;

Table 1. Contrasts between positivism and post-positivism

\begin{tabular}{|c|c|}
\hline Positivism & Post-Positivism \\
\hline $\begin{array}{l}\text { Emphasis on parts and de- } \\
\text { contextualization }\end{array}$ & Emphasis on whole and contextualization \\
\hline Emphasis on separation & Emphasis on integration \\
\hline Emphasis on the general & Emphasis on the specific \\
\hline $\begin{array}{l}\text { Consideration only of objective and the } \\
\text { quantifiable }\end{array}$ & $\begin{array}{l}\text { Consideration also of subjective and the } \\
\text { non-quantifiable }\end{array}$ \\
\hline $\begin{array}{l}\text { Reliance on experts and outsider } \\
\text { knowledge--researcher as external }\end{array}$ & $\begin{array}{l}\text { Consideration also of the "average" } \\
\text { participant and insider knowledge-- } \\
\text { researcher as internal }\end{array}$ \\
\hline Focus on control & Focus on understanding \\
\hline Top-down & Bottom-up \\
\hline Attempt to standardize & Appreciation of diversity \\
\hline Focus on the product & Focus on the process as well \\
\hline
\end{tabular}


In general there are eight major changes in learning Second Language Education associated with this shift. These eight changes are Learner autonomy, Cooperative Learning, Curricular integration, Focus on meaning, Diversity, Thinking skills, Alternative assessment, Teachers as co-learners. Figure 1.1 illustrates the interdependence of these eight changes of the paradigm shift in second language education. The circular nature of the figure emphasizes that all the changes are parts of a whole and the successful implementation of one change depends on the others.

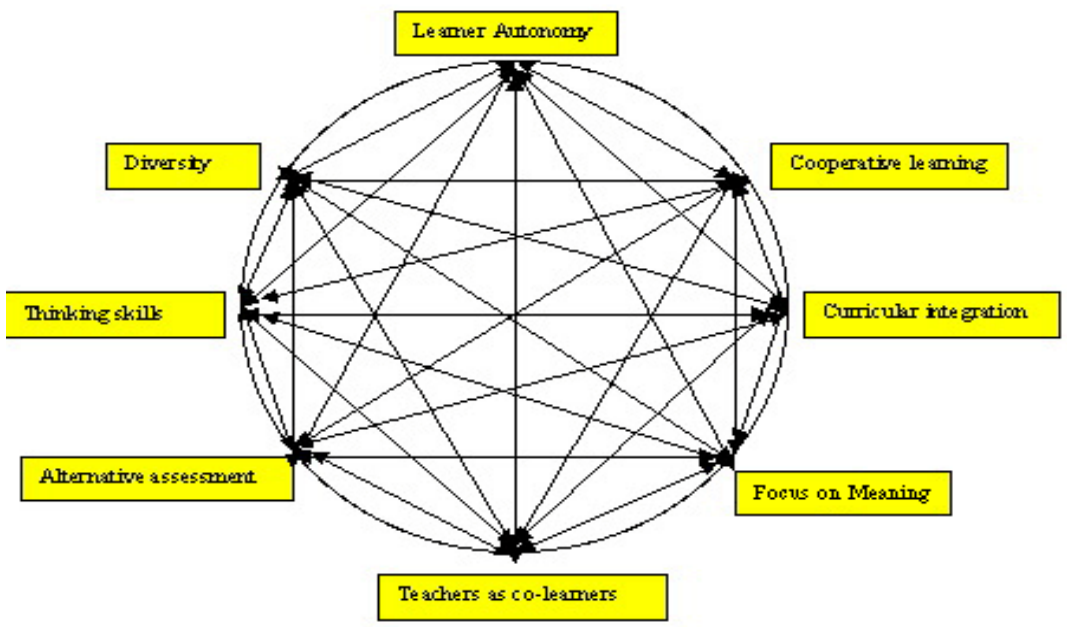

Figure 1.1. Eight Changes in Second Language Teaching ((Jacobs dan Farrel, 2004)

Academic policy is also one of the ways to see the paradigm shift as the implementation of second language education paradigm in an institution. In this regard, the Center for Quality Assurance / Kantor Jaminan Mutu, UGM (2012) states that academic policy is a policy direction and guidance for managing the academic affairs. Academic 
policy is released in both university level/ institute and the faculty level. Academic policy of UGM include:

1. Education services division includes the Mission and Purpose, Program, Resources, Evaluation of program and institutional affairs.

2. Research services division covers Mission and Objectives, Research Program, Resources, Evaluations of Program and institutional affairs 3. The Community Services division includes the Mission and Objectives, Program, Resources, Evaluation of program and institutional affairs. 4. Principles of Operation.

Academic policy is described by standardized academic affair and is implemented based on the academic regulation. Academic Regulation is a software system for the implementation of the academic education that will be implemented to the whole academic community in which each community has a set of Specific study program.

Specific study program is a brief description of the study program that functions to communicate between the students and the stakeholders. Specific study program indicates explicitly the desired results of the learning process. It helps students to understand: teaching and evaluation methods used. It makes a link between a program organized and professional qualifications as the output of graduates as well as its influence on their career level. it helps students in determining the courses will be taken. It is not only as a label of university and as an institution's responsibility to the public, but also to provide stimulus to the faculties to understand and to implement the educational goals and learning outcomes of the program being organized.

Based on the theoretical descriptions above, the researcher aims to report the results of research on the analysis of textual paradigm of English 
Language Education has been conducted in ELE HKU and PBI IAIN Surakarta. The followings are the results and discussions.

\section{Research Methods}

Descriptive Qualitative is used in this study specifically in the form of textual analysis. Two Universities are the Setting of the study. They are the Division of English Language Education (ELE) Hong Kong University and the English Language Education Department IAIN Surakarta. The data collected in this study are in the form of words about paradigms and academic policy in both universities. The researcher collected the data from the documents and informants in both universities. The instruments used to collect the data are document analysis and interviews. Data were analyzed using the Miles and Huberman interactive model. The validity of research was obtained through the triangulation methods and data sources. Results and Discussion

Based on the textual analysis reffering to the theory of paradigm shift in second or a foreign language teaching (EFL / ESL) which includes what, how and why (Kostoulas 2010) as well as the description of academic policy based on the Center for Quality Assurance UGM (2012) on data obtained from documents that confirmed to informants from both universities, the result of comparison of paradigms and policy for English in both universities can be seen in Table 1, 2, and 3, below. 
Table 1 Paradigm shift description and the policy in ELE HKU

\begin{tabular}{|c|c|c|}
\hline Vis & $\begin{array}{l}\text { Vision } \\
\text { of Educ }\end{array}$ & $\begin{array}{l}\text { Details on ELE divisio } \\
\text { HKU }\end{array}$ \\
\hline $\begin{array}{l}\text { Vision } \\
\text { The University of Hong } \\
\text { Kong, as a leading } \\
\text { international institution of } \\
\text { higher learning in Asia, } \\
\text { strives to attract and nurture } \\
\text { outstanding scholars from } \\
\text { around the world through } \\
\text { excellence and innovation in } \\
\text { teaching and learning, } \\
\text { research and knowledge } \\
\text { exchange, contributing to the } \\
\text { advancement of society and } \\
\text { the development of leaders } \\
\text { through a global presence, } \\
\text { regional significance and } \\
\text { engagement with the rest of } \\
\text { China. } \\
\text { Mission } \\
\text { The University of Hong } \\
\text { Kong will endeavour: } \\
\text { the bounds of } \\
\text { aponolarship, building } \\
\text { andrengths } \\
\text { Troud traditions } \\
\text { Tonsive }\end{array}$ & $\begin{array}{l}\text { The Faculty of Education } \\
\text { aspires to lead the study and } \\
\text { practice of education, to } \\
\text { influence public policy and } \\
\text { improve community life } \\
\text { through education, and to } \\
\text { nurture graduates who are } \\
\text { passionately committed to } \\
\text { their professions. } \\
\text { Mission } \\
\text { In realizing our vision, we } \\
\text { will endeavour: } \\
\text { - } \\
\text { To advance scholarship } \\
\text { and engage in research } \\
\text { with high impact } \\
\text { internationally, } \\
\text { nationally and locally; } \\
\text { To break new ground } \\
\text { in curriculum and } \\
\text { pedagogy, and to be a } \\
\text { committed to lifelong } \\
\text { learning, ethical } \\
\text { educational practice; } \\
\text { To nurture graduates of } \\
\text { dinction with a } \\
\text { - }\end{array}$ & $\begin{array}{l}\text { - Students will develop } \\
\text { in-depth knowledge } \\
\text { of English language } \\
\text { and linguistics, } \\
\text { literature, } \\
\text { communication and } \\
\text { Language acquisition } \\
\text { and will critically } \\
\text { explore issues in } \\
\text { language education } \\
\text { and develop personal } \\
\text { strengths and } \\
\text { commitment to } \\
\text { education. } \\
\text { The programme } \\
\text { offers two Degrees in } \\
\text { one. It is equivalent } \\
\text { to a BA plus a } \\
\text { Postgraduate } \\
\text { Diploma in } \\
\text { Education, a } \\
\text { professional teaching } \\
\text { qualification } \\
\text { recognized in Hong } \\
\text { Kong schools and } \\
\text { internationally. }\end{array}$ \\
\hline
\end{tabular}




\begin{tabular}{|c|c|c|}
\hline $\begin{array}{l}\text { education, developing } \\
\text { fully the intellectual and } \\
\text { personal strengths of its } \\
\text { students while } \\
\text { developing and } \\
\text { extending lifelong } \\
\text { learning opportunities } \\
\text { for the community } \\
\text { To produce graduates of } \\
\text { distinction committed to } \\
\text { lifelong learning, } \\
\text { integrity and } \\
\text { professionalism, } \\
\text { capable of being } \\
\text { responsive leaders and } \\
\text { communicators in their } \\
\text { fields } \\
\text { To develop a collegial, } \\
\text { flexible, pluralistic and } \\
\text { expression } \\
\text { supportive intellectual } \\
\text { environment that } \\
\text { inspires and attracts, } \\
\text { retains and nurtures } \\
\text { scholars, students and } \\
\text { staff of the highest } \\
\text { calibre in a culture that } \\
\text { fosters creativity, } \\
\text { learning and freedom of } \\
\text { enquiry and } \\
\text { entions }\end{array}$ & $\begin{array}{l}\text { practice and } \\
\text { professionalism, and } \\
\text { capable of becoming } \\
\text { leaders in their fields; } \\
\text { To engage in } \\
\text { productive partnerships } \\
\text { with academic and } \\
\text { professional } \\
\text { communities in order } \\
\text { to generate, integrate, } \\
\text { exchange and apply } \\
\text { knowledge, build } \\
\text { capacity, and enhance } \\
\text { educational } \\
\text { opportunities for all; } \\
\text { To serve as a focal } \\
\text { point of intellectual and } \\
\text { academic excellence in } \\
\text { our fields of expertise } \\
\text { in Hong Kong, China } \\
\text { and Asia, and act as a } \\
\text { supportive, flexible and } \\
\text { multicultural } \\
\text { environment that will } \\
\text { scholarship with the } \\
\text { rest of the world; } \\
\text { To and nurture } \\
\text { and staff of the }\end{array}$ & 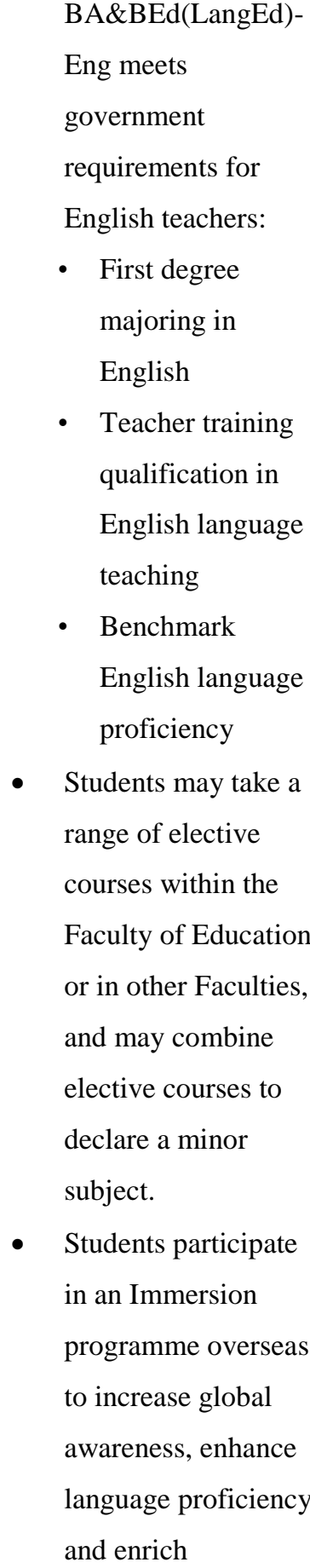 \\
\hline
\end{tabular}




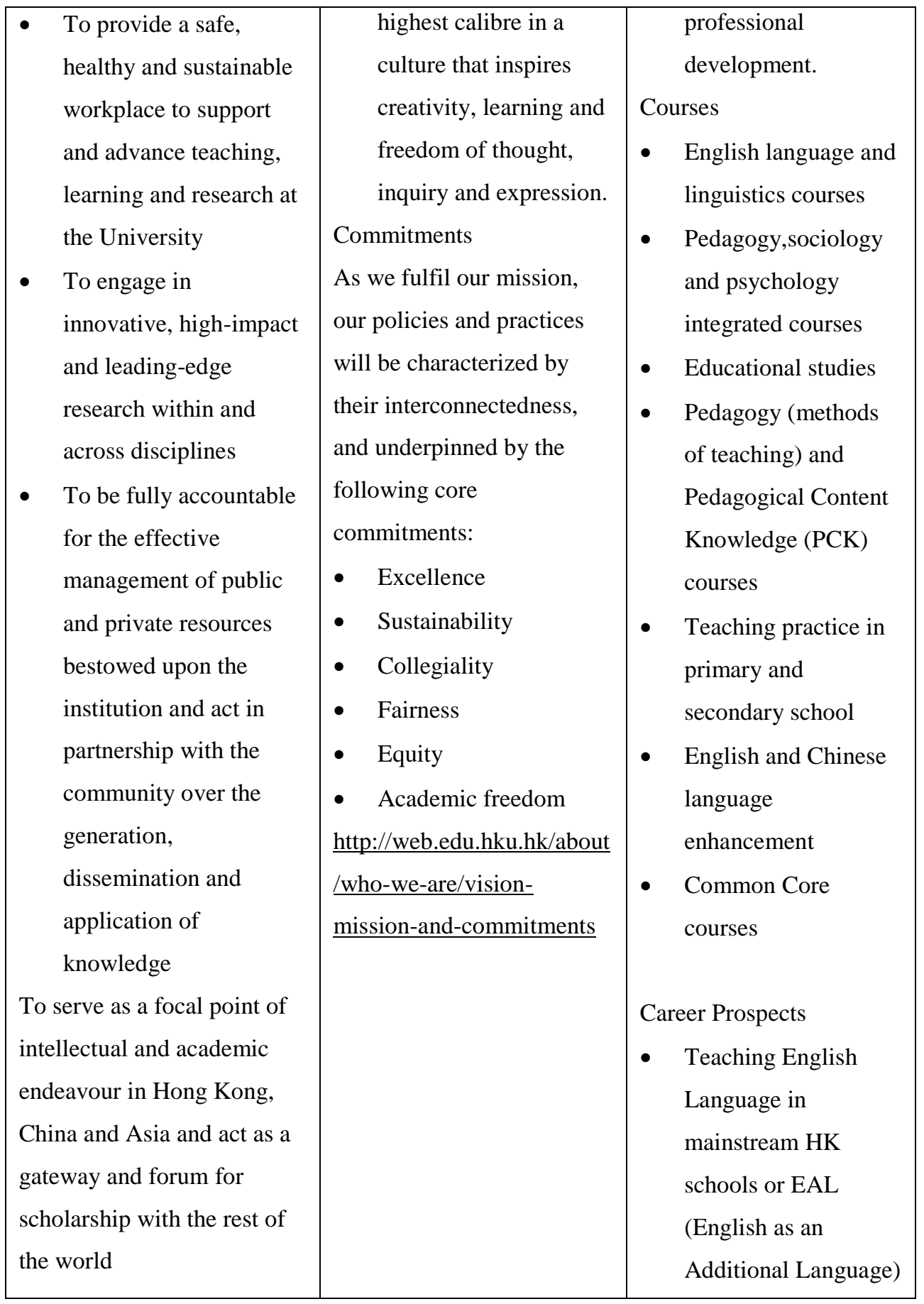


Teaching and Learning English Paradigm and

The Implementation of The Policy

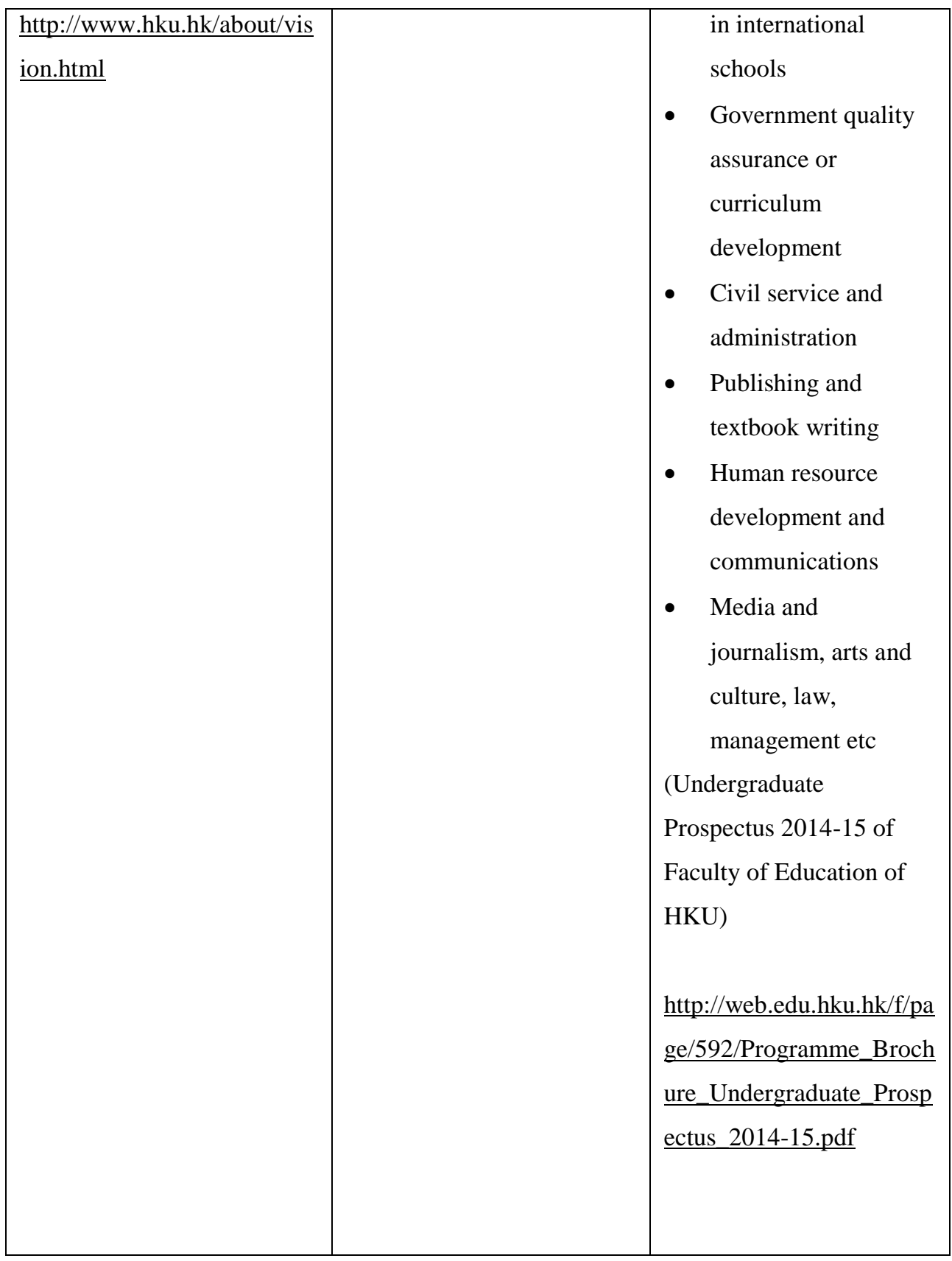


Table 2 Paradigm shift description and the policy in ELE, IAIN Surakarta

\begin{tabular}{|c|c|c|}
\hline $\begin{array}{l}\text { Vision and mission } \\
\text { IAIN Surakarta }\end{array}$ & $\begin{array}{l}\text { Vision and mission } \\
\text { Faculty of } \\
\text { Education and } \\
\text { teachers training, } \\
\text { IAIN Surakarta }\end{array}$ & $\begin{array}{l}\text { Details on ELE division IAIN } \\
\text { Surakarta }\end{array}$ \\
\hline $\begin{array}{l}\text { Vision of IAIN } \\
\text { Surakarta is to make } \\
\text { the institute as an } \\
\text { institution of higher } \\
\text { islamic education and } \\
\text { independent of } \\
\text { education, research } \\
\text { and community } \\
\text { service, as well as the } \\
\text { center of Islamic } \\
\text { studies and social } \\
\text { transformation } \\
\text { Mission IAIN } \\
\text { Surakarta: } \\
1 . \text { education, } \\
\text { research and } \\
\text { community service- } \\
\text { oriented on social } \\
\text { transformation as } \\
\text { the agent of change. } \\
2 . \text { Developing } \\
\text { campus life in }\end{array}$ & $\begin{array}{l}\text { vision } \\
\text { Being an excellent } \\
\text { faculty to shape } \\
\text { professional } \\
\text { graduates in the } \\
\text { field of education } \\
\text { and language, have } \\
\text { strong akidah, and } \\
\text { good character. } \\
\text { mission } \\
\text { 1. Organizing } \\
\text { education and } \\
\text { teaching by } \\
\text { developing } \\
\text { students' character } \\
\text { of islam, high } \\
\text { quality in } \\
\text { education, and } \\
\text { technology based to } \\
\text { meet the } \\
\text { development of }\end{array}$ & $\begin{array}{l}\text { Become an excellent study } \\
\text { program to produce the good } \\
\text { quality of graduates that having } \\
\text { strong akidah and akhlaqul } \\
\text { karimah and deeper } \\
\text { understanding in both } \\
\text { theoretically and practically in } \\
\text { Teaching English. } \\
\text { mission } \\
\text { 1. To organize educational } \\
\text { services, learning services, and } \\
\text { teaching Islamic sercvices, } \\
\text { character building, high quality } \\
\text { education, and technology based } \\
\text { to meet the requirement of } \\
\text { English language teachers and } \\
\text { educators. } \\
2 . \text { To conduct research for the } \\
\text { development of pedagogical }\end{array}$ \\
\hline
\end{tabular}




\begin{tabular}{|c|c|c|}
\hline $\begin{array}{l}\text { Islamic atmosphere. } \\
\text { Preparing the } \\
\text { students to have } \\
\text { good knowledge (al- } \\
\text { ilmu, akhlaq, and } \\
\text { 'amal shaleh) } \\
\text { 3. Encouraging } \\
\text { students islamic } \\
\text { thought. Preparing } \\
\text { students to have } \\
\text { wider knowledge, } \\
\text { insightful, } \\
\text { competitive, and } \\
\text { able to meet people's } \\
\text { needs and ready to } \\
\text { face the global } \\
\text { challenges based on } \\
\text { Islamic values. }\end{array}$ & $\begin{array}{l}\text { education and the } \\
\text { need of society. } \\
\text { 2. Conducting } \\
\text { research for the } \\
\text { development of } \\
\text { educational science } \\
\text { and language. } \\
\text { 3. Giving } \\
\text { community services } \\
\text { for the development } \\
\text { and implementation } \\
\text { of educational and } \\
\text { linguistic sciences. } \\
\text { 4. Establishing an } \\
\text { Islamic } \\
\text { environment and } \\
\text { culture. }\end{array}$ & 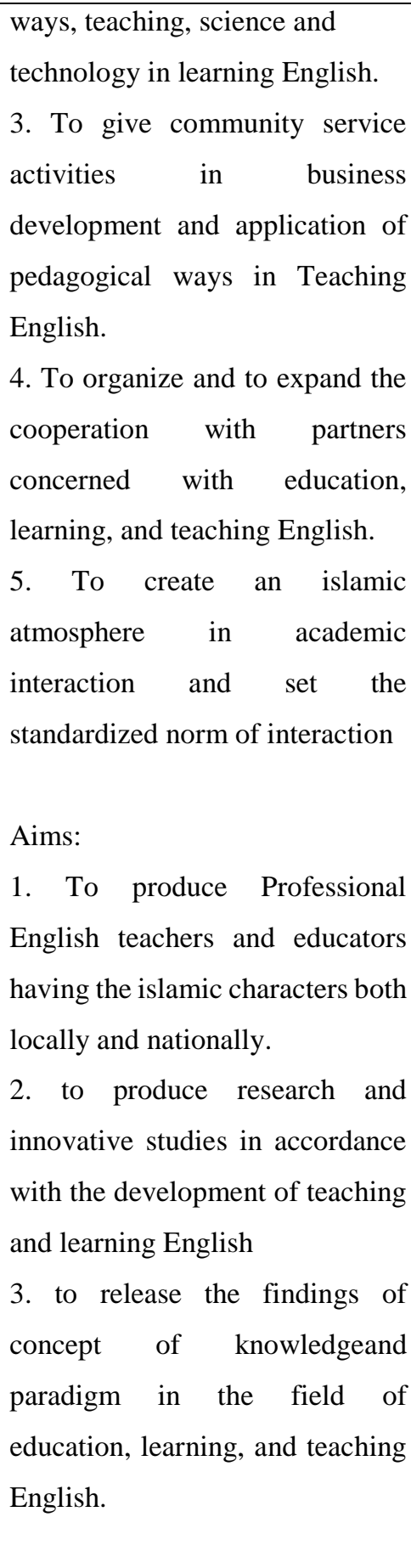 \\
\hline
\end{tabular}




\begin{tabular}{|c|c|c|}
\hline $\begin{array}{l}\text { 3. To disseminate } \\
\text { knowledge, science } \\
\text { and technology and } \\
\text { slamic art. } \\
\text { 4. To promote the use } \\
\text { ff science, science } \\
\text { and technology and } \\
\text { slamic arts in order } \\
\text { o improve the } \\
\text { quality of people's } \\
\text { ives. } \\
\text { Rencana Induk } \\
\text { Pengembangan IAIN } \\
\text { Surakarta 2010-2015) }\end{array}$ & 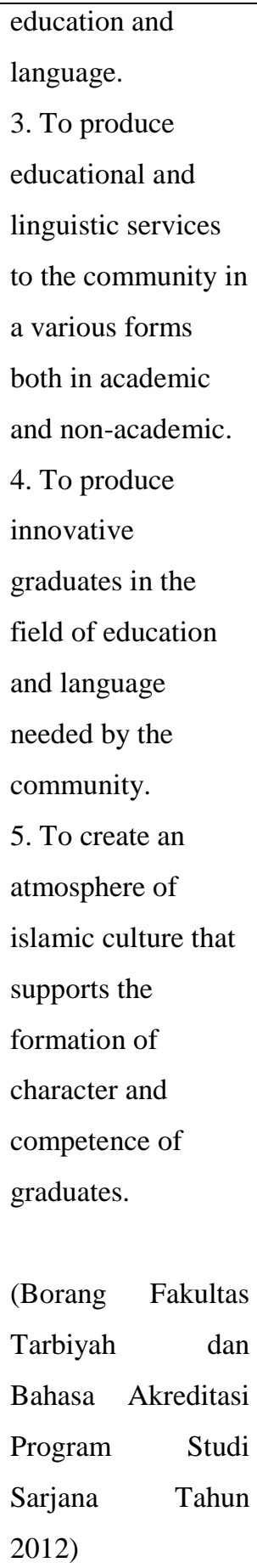 & $\begin{array}{l}\text { 4. to Produce English language } \\
\text { education services to the } \\
\text { community in a variety of forms } \\
\text { both in academic and non- } \\
\text { academic in accordance with the } \\
\text { development of science and } \\
\text { technology. } \\
\text { 5. to create professional academic } \\
\text { interactions and to support } \\
\text { character building and graduates } \\
\text { competence. } \\
\text { 6. to Produce the Memorandum of } \\
\text { Understanding with some } \\
\text { universities to develop the } \\
\text { institution. } \\
\text { 7. to Provide good infrastructure } \\
\text { in the learning process in Islamic } \\
\text { - Mays. } \\
\text { - Pualitative, and Action } \\
\text { - Presrach methodology, } \\
\text { - Social Competence. } \\
\text { - maduates: }\end{array}$ \\
\hline
\end{tabular}




\begin{tabular}{|l|l|l|}
\hline & $\begin{array}{l}\bullet \text { having good ability to translate } \\
\text { the text from English-Indonesia } \\
\text { or vice versa }\end{array}$ \\
& $\begin{array}{l}\text { Elective course/ competence } \\
\bullet \text { Guiding } \\
\bullet \text { Translation entrepreneurship, } \\
\bullet \text { Hospitality and travel handling. }\end{array}$ \\
& $\begin{array}{l}\text { (Borang Akreditasi Prodi } \\
\text { Pendidikan Bahasa Inggris 2012) }\end{array}$ \\
\hline
\end{tabular}

Table 1 Paradigm shift comparison between ELE HKU and ELE IAIN Surakarta

\begin{tabular}{|c|c|c|c|}
\hline $\begin{array}{l}\text { Paradigm } \\
\text { aspects } \\
\text { ESL/EFL } \\
(\text { Kostoulas } \\
2010) \text { ) }\end{array}$ & ELE HKU & PBI IAIN Surakarta & $\begin{array}{l}\text { Keteranga } \\
\mathrm{n}\end{array}$ \\
\hline What & $\begin{array}{l}\text { - English language and } \\
\text { linguistics courses } \\
\text { - Pedagogy,sociology and } \\
\text { psychology integrated } \\
\text { courses } \\
\text { - Educational studies } \\
\text { - Pedagogy (methods of } \\
\text { teaching) and Pedagogical }\end{array}$ & $\begin{array}{l}\text { Main competence: } \\
\text { - } \quad \text { Pedagogical } \\
\text { competence, } \\
\text { - Personality competence, } \\
\text { - Professional } \\
\text { competence, } \\
\text { Social competence, } \\
\text { Supporting competence }\end{array}$ & $\begin{array}{l}\text { Both } \\
\text { universiti } \\
\text { es offer } \\
\text { the } \\
\text { similar } \\
\text { learning } \\
\text { content. }\end{array}$ \\
\hline
\end{tabular}




\begin{tabular}{|c|c|c|c|}
\hline & $\begin{array}{l}\text { Content Knowledge (PCK) } \\
\text { courses } \\
\text { - Teaching practice in } \\
\text { primary and secondary } \\
\text { school } \\
\text { - English and Chinese } \\
\text { language enhancement } \\
\text { - Common Core courses }\end{array}$ & 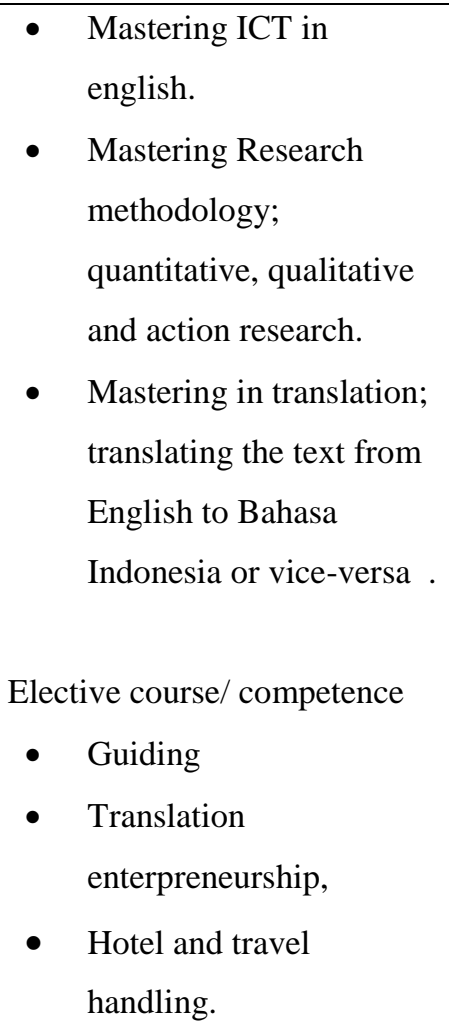 & \\
\hline How & $\begin{array}{l}\text { Integrated Course } \\
\text { E-learning } \\
\text { Experiential Learning }\end{array}$ & $\begin{array}{l}\text { Individual Subject } \\
\text { Communicative Langguage } \\
\text { Teaching } \\
\text { Theoretical lecture } \\
\text { Practice } \\
\text { Project Based Learning }\end{array}$ & $\begin{array}{l}\text { Each } \\
\text { universit } \\
\text { y has } \\
\text { different } \\
\text { way in } \\
\text { offering } \\
\text { the } \\
\text { learning } \\
\text { content. }\end{array}$ \\
\hline Why & $\begin{array}{l}\text { Explaining the vision, } \\
\text { mission and strategic plan of } \\
\text { the university based on the } \\
\text { need of both local and }\end{array}$ & $\begin{array}{l}\text { Explaining the vision and } \\
\text { mission of the university based } \\
\text { through developing the } \\
\text { curriculum that refers to the }\end{array}$ & $\begin{array}{l}\text { Both } \\
\text { universiti } \\
\text { es have } \\
\text { the reason }\end{array}$ \\
\hline
\end{tabular}




\begin{tabular}{|l|l|l|l|}
\hline $\begin{array}{l}\text { international society that } \\
\text { refers to the central } \\
\text { goverment's plan, and } \\
\text { supported by the human } \\
\text { resources. }\end{array}$ & $\begin{array}{l}\text { curriculum from the central } \\
\text { goverment, the needs of local } \\
\text { societies and SWOT of } \\
\text { department. }\end{array}$ & $\begin{array}{l}\text { sased on } \\
\text { situationa }\end{array}$ \\
\hline
\end{tabular}

\section{Discussion}

Based on the intertextual analysis above, it can be said that the paradigm and policy on teaching English in IAIN Surakarta still refer to the dominant paradigm or teaching paradigm and begin to face the paradigm shift and the changes will be based on the situational context and political policy on education which is the government regulations.

like the English Language Education department in Indonesia, the paradigm of English education at the department of English Language Education IAIN Surakarta is implementing the Curriculum from the central goverment (the Ministry of National Education). English Language Education (ELE) paradigm that developed in Indonesia is dynamic. Its paradigm shift happening today is derrived from the base of curriculum. The Base is is currently being shifted from competency-based curriculum (CBC) to Outcomes-based curriculum (Imroatus Sholihah, 2014c).

Currently the new curriculum in ELE Department is still on the preparation stage. The main stage is formulating KKNI. It has been done by running the workshop on formulating KKNI conducted by Center for Quality Assurance (LPM) IAIN Surakarta. The aim of the workshop was directed to run the paradigm shift launched by the government. This paradigm shift is based on the premise that indonesia will be able to survive 
and to keep moving forward in the global economic place. The mutual understanding will be considered to develop national labor qualifications (Minister of Education, 2010: 4). KKNI is a hierarchy of qualifications of the competence that can reconcile, equalize, and integrate between the field of education and vocational training in accordance with the structure of employment in various sectors (Perpres No. 8 Tahun 2012 Pasal 1 Ayat (1)).

The results of the interview with some of the lecturers in the Department of PBI IAIN Surakarta showed the tendency of some lecturers began to use learner centered method. Some instructors have already applied Project Based Learning. In fact, there are problems in the implementation of the Teaching and Learning method they use. The problems are mainly related to the academic policy that has not given yet to support the process of learning by those methods that tend to embrace learning paradigm integratively and cooperatively. Another problem is mainly related to inadequate infrastructure facilities and resources, so the learning process can not run succesfully and the learning objectives can not be achieved optimally.

This case is very different from the situation existing at ELE Hong Kong University as a new paradigm shift called learning paradigm. This happen because the paradigm and the policy of English Language Education at ELE Hong Kong University has been adapted to the needs of the global market as stipulated in the vision, mission, strategic plan and it is supported by good quality of human resources to meet standardized graduate set by the government. Therefore learning programs, assessment programs and agencies have already referring to international standards. 
The Hong Kong University, the reformation of Educational curriculum on undergraduate level has been started since 2012, which was the "total learning experience". Experiential learning as the example is not only the method used by course instructors to teach but it has been a learning system applied throughout the university and protected by policies to maintain and improve the quality of teaching and provided by completed infrastructure and facilities to build a new educational paradigm atmosphere. It can be understood from the following quote:

In the past decade, HKU witnessed a historic reform in its undergraduate education. The new undergraduate curriculum was successfully implemented in September 2012. HKU took full advantage of this opportunity to re-envision our curriculum as a 'total learning experience'. We have introduced new and innovative forms of learning, upgraded our infrastructure and extended learning into all corners of university life (The University of Hong Kong)

The figure of curriculum at $\mathrm{HKU}$ can be seen from the following table.

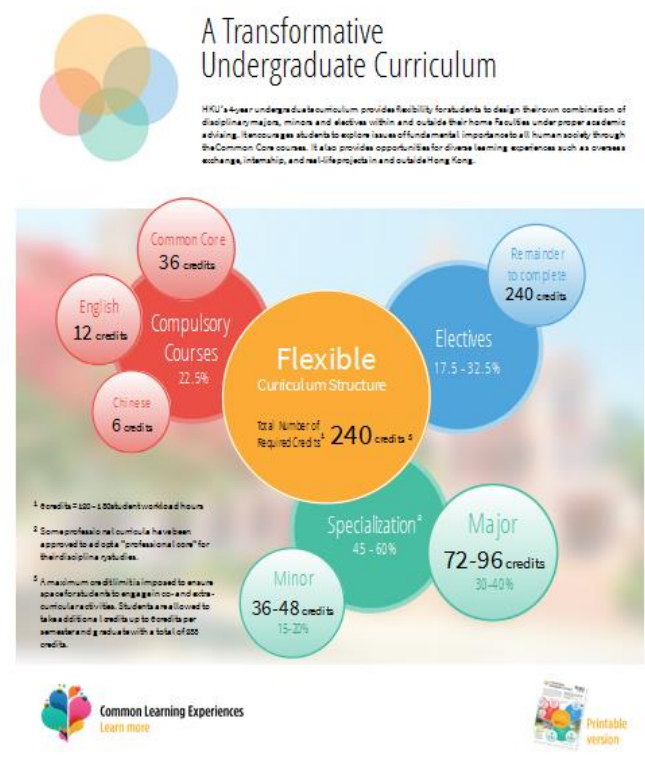

Chart 3. A Transformative Undergraduate Curriculum in HKU 
Experiential Learning system in teaching and learning is the combination between experential and outdoor activity which is formulated into standardized formal curriculum for the profession program and is still proposing for non-profession program.

Experiential learning also enacted at the university level in the form of the student exchange program that supports the international reputation on campus and at the same time students who returned after being sent overseas will support their maturity and have a good quality of human resources after obtaining a rich learning experience and the different education environment, social and cultural as stated in the following quote:

The incorporation of experiential and 'out of classroom' learning into the formal curriculum is standard practice in professional programmes and is increasingly being formalized in nonprofessional programmes at HKU. This bottom-up initiative has been made one of the common learning experiences in the 4-year curriculum.Other experiential learning is also organised at University level. The HKU Worldwide Student Exchange Programme administers reciprocal academic student exchanges with over 280 partner institutions in 37 countries. Incoming exchange students contribute to internationalising the campus while outgoing undergraduates invariably return as more mature and resourceful individuals after having acquired a rich learning experience in a different educational, social and cultural environment (The University of Hong Kong)

Experiential learning system at HKU is the combination among Outcomebased Approach to Student Learning (OBASL), Problem-based Learning and Co-curricular Learning. The objective of the OBASL at HKU is to involve students in-depth understanding as in the following passage: 
The ultimate goal is to engage students in deep understanding (deep learning) rather than a surface factual recall (surface learning) which teaching and learning research indicates is achieved through clear understanding and appreciation of the Learning Outcomes (The University of Hong Kong)

While the Problem-Based Learning and student-centered learning at the university are to encourage the students learn actively. As the following statement.

The University adopts problem-based and student-centred learning to stimulate active learning among students. Authentic problems or situations are used as a way of stimulating students to discover and explore the key concepts and skills of the discipline in class, while teachers act as facilitators and guides in the process. This new learning method helps students to reason their way through problems, to think critically, and to learn to become self-directed lifelong learner (The University of Hong Kong)

Co-curicular Learning Center managed by a specific unit and is integrated into the curriculum at the university level and faculty as the following:

The Centre of Development and Resources for Students

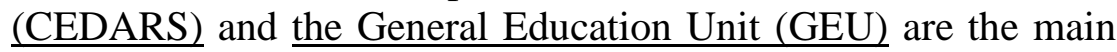
providers of co-curricular non-credit-bearing learning activities at HKU. Students also engage in community service or advocacy projects which typically entail a process of training, service and reflection. CEDARS liaises with Faculties on how to better integrate service learning with the formal curriculum (The University of Hong Kong) 
Learning description at HKU can be seen as follows:

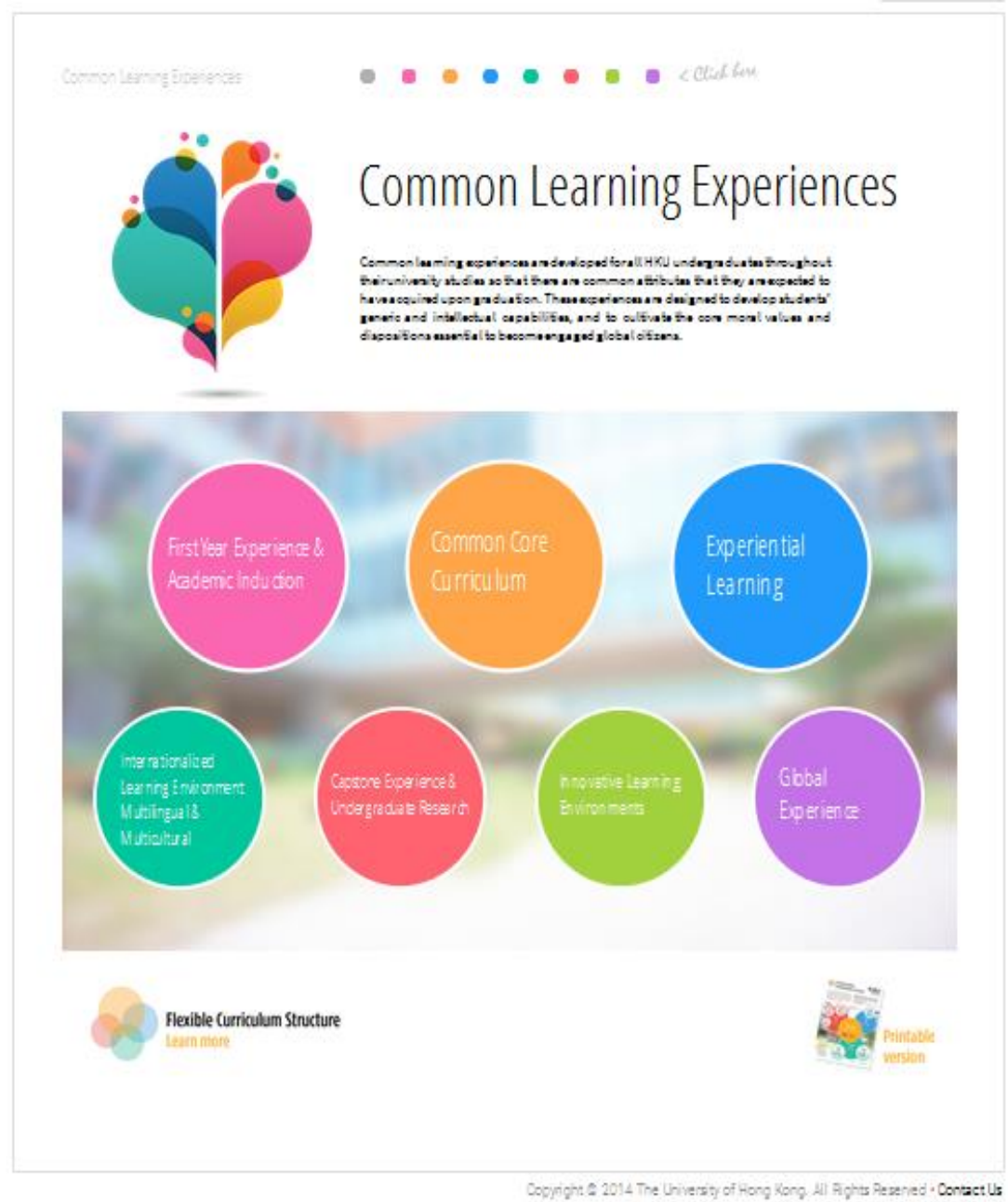

Chart 4. Common earning Expereinces di HKU

Good Facilities and the good learning support systems at HKU support the learning paradigm. 
The following chart explains the facilities.

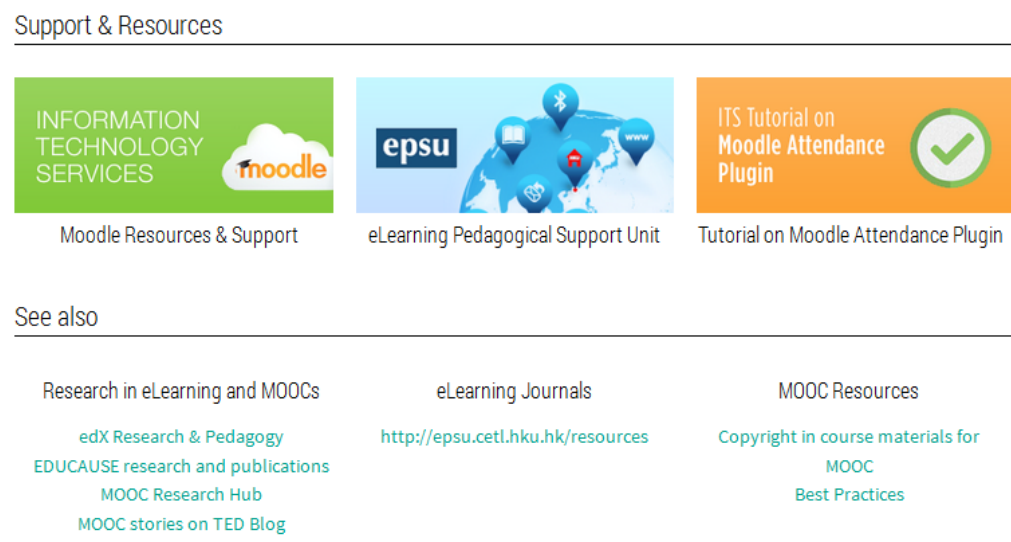

Chart 5 Support and Resources in HKU

\section{Hypothesis}

Based on the description above, the conclusion is the paradigm and the policy on both the Division of English Language Education of the Hong Kong University and English Language Education Department of IAIN Surakarta are influenced by situational context, cultural context and the orientation of each college. In the formulation of the vision, mission and strategic plans of the Division or Department is influenced by the educational policy of the ruling government, market needs, and the resources of the University.

\section{Conclusion}

Theory on Teaching English is currently moving on a paradigm shift. This paradigm occurred because of a review on the basics of linguistic, pedagogic and the review on the impact of sociolinguistics in a 
globalized setting. The results show that the content of English Language Education taught at the Division of English Language Education (ELE) HKU and at the English Language Education Department (PBI) IAIN Surakarta have the same characteristics but the ways in providing educational materials are relatively different. The paradigm and academic policiy in ELE HKU applied the learning paradigm while at PBI IAIN Surakarta is still applying on teaching paradigm. When the study was conducted by researcher, the ELE Department IAIN Surakarta has been moving towards a paradigm shift in some academic elements as the use of the methods by lecturers called learning paradigm, although the method is not covered by the policy. The difference between Paradigm and policy in both universities is influenced by the context of the political situation, especially the rules of ministry of higher education, cultural context and the orientation on each university.

\section{References}

Barr, R. B. dan John, T. (1995). From Teaching to Learning - A New Learning Paradigm for Undergraduate Education in Change. November/December 1995.San Marcos California

Capano, G. (2003). Administrative Traditions and Policy Change: When Policy Paradigms Matter. The Case of Italian Administrative Reform During the 1990s di Public Administration Vol. 81, Issue 4 pages 781-801 decemeber 2003. John Wiley \& Sons, Inc. 
Depdiknas. (2010). Buku Pedoman Kerangka Kualifikasi Nasional Indonesia. Jakarta: Direktorat Jendral Pendidikan Tinggi.

Farrell, T.S.C. and George, M. J. (2004) Paradigm Shift: Understanding and Implementing Change in Second Language Education in TESL-EJ.org

Hill, D. 1999. "Education, Education, Education', or 'Business, Business, Business'?' Paper presented at the European Educational Research Association Annual Conference, Lahti, Finland, 22-25 September, 1999, p. 16.

Kantor Jaminan Mutu Universitas Gadjah Mada. (2012). Sistem Penjaminan Mutu Perguruan Tinggi Ditjen Dikti Menuju Insan Indonesia Cerdas dan Kompetitif disampaikan dalam Pelatihan Sistem Penjaminan Mutu Internal Perguruan Tinggi (SPMI-PT) 10 - 11 April 2012.

Kostoulas, 2010 Between Paradigms: A case study of a language school in Greece Achilleas Kostoulas Paper presented at the 13th International Conference on Intercultural Education; Alexandroupolis, Greece. Reprinted in Georgogiannis \& Baros (2010). 13th International Conference on Intercultural Education (vol.1, pp. 391-410). Patras: University of Patras May 2010

Milles, M.B. and Huberman, M.A. 1984. Qualitative Data Analysis. London: Sage Publication 